\title{
O TRAJE DE CENA E A VISUALIDADE TEATRAL
}

\section{COSTUME AND VISUAL DESIGN FOR THEATRE}

Tainá Macêdo Vasconcelos macedo.vasconcelos@gmail.com

Doutoranda em artes cênicas, na Escola de Comunicação e Artes, da Universidade de São Paulo. Professora assistente da Licenciatura em Teatro da Universidade Federal do Amapá.

\section{Resumo:}

Esse artigo conceitua traje de cena compreendendo-o como aspecto visual do fazer teatral, a partir das ideias de Patrice Pavis (1999) e Fausto Viana (2014). Também visa refletir sobre a importância do figurino como significante cênico, que compõe um espetáculo junto aos outros elementos teatrais. Abrangendo também a função do figurinista e suas especificidades.

Palavras-chave: traje de cena, visualidade, teatro.

\section{Abstract:}

This essay conceptualizes costume understanding it as the visual aspect of theatrical making, from the ideas of Patrice Pavis (1999) and Fausto Viana (2014). Also aims to reflect about the importance of performing costume as a scenic signifier, which composes a spectacle with others theatrical elements. Covering also the role of the costume designer and its specificities.

Keywords: Costume design, visual, theater.

\author{
Todo esplendor \\ É nada \\ O que encanta \\ São as \\ Invisibilidades \\ Lau Siqueira (2011)
}

No mundo atual, o apelo visual é constante. As mídias, a publicidade e a comunicação tem se aproveitado da imagem para alcançar cada vez um público maior. No teatro não é diferente. A imagem tem se tornado cada vez mais importante na prática teatral. Quando relacionada ao texto ou ação, a visualidade tem alcançado maior espaço de percepção e compreensão por parte do espectador. $\mathrm{O}$ processo de comunicação existente no teatro acontece com maior facilidade pelo sentido da visão. 
Ao falar sobre visualidade, entende-se que o universo das imagens implica em representações.

\begin{abstract}
O mundo das imagens se divide em dois domínios. O primeiro é o domínio das imagens como representações visuais: desenhos, pinturas, gravuras, fotografias e as imagens cinematográficas, televisivas, holo e infográficas pertencem a esse domínio. Imagens, nesse sentido, são objetos materiais, signos que representam o nosso meio ambiente visual. O segundo é o domínio imaterial das imagens na nossa mente. Neste domínio, imagens aparecem como visões, fantasias, imaginações, esquemas, modelos ou, em geral, como representações mentais (SANTAELLA; NÖTH, 2010, p.15).
\end{abstract}

Com isso, compreende-se que as imagens podem ser captadas de duas maneiras, através de representações visuais, ou mentais, mas isso não é restritivo, podem existir outras disposições referentes $\mathrm{a}$ isso. A imagem enquanto representação visual, está vinculada a algo físico que contém signos que representam alguma coisa. Uma fotografia, é um objeto que possui significados através do que foi enquadrado naquele momento. No teatro, a imagem enquanto representação visual está presente do início ao fim, pois o espetáculo cria imagens diferentes a cada movimentação do ator, da iluminação e do figurino em relação ao cenário.

As imagens também podem ser percebidas enquanto representações mentais. As imagens podem ser criações do consciente e do subconsciente, são obras do pensamento. Geralmente, a criança cria um monstro debaixo da cama por uma representação mental. No teatro, a compreensão do espetáculo está permeada por imagens enquanto representações mentais. Os pensamentos suscitam ideias em forma de imagens. A fala de uma personagem pode levar o espectador a imaginar algo, criando assim uma imagem mental.

A imagem, para Patrice Pavis (1999), é vista como uma "construção da maquinaria teatral" (p. 204), com sua própria maneira de organização. É o entendimento do espetáculo por meio de representações, que envolvem o público de maneira coletiva pela visualidade exposta, e individualmente pela elaboração mental de cada um.

Esses são alguns exemplos simples sobre como as imagens estão presentes no cotidiano teatral. Isso se tornou tão importante, que alguns encenadores passaram a elaborar os espetáculos a partir da visualidade. Surgiu assim o Teatro de Imagens, que trata os signos teatrais como componentes de um quadro imagético. O espetáculo teatral passa a ser construído como uma sucessão de quadros que alcançam o espectador pela qualidade visual, e pela possibilidade 
de diferentes leituras pelo público. O teatro de Robert Wilson é um exemplo dessa vertente cênica.

Para tornar mais claro, considera-se que no teatro existem dois processos de significação, o visual e o verbal (textual e sonoro). Os signos visuais constroem a imagem do espetáculo, são eles o ator, a cenografia, o figurino e a iluminação. Os signos verbais se confundem com os sonoros, sendo assim a fala das personagens e a sonoplastia. A sincronia entre esses dois sistemas permite passar de um para o outro sem dificuldade, e isso contribui para a compreensão do espetáculo como um todo.

O ato de encenar é um ajuste dos elementos visuais e textuais para a construção cênica. Sobre a ação teatral, Pavis afirma que "a encenação diz mostrando" (1999, p. 431). A encenação teatral existe para ser visualizada. A leitura de uma encenação é compreendida através de diversos elementos verbais e visuais, em alguns momentos esses elementos provocam diferentes leituras, mas o intuito é fazer com que a mensagem alcance o público sem problemas.

Existem diferenças entre os elementos visuais e os verbais, umas são claras e outras mais complexas. Pavis (1999) apresenta um quadro de oposições entre os sistemas visual e verbal no teatro. O sistema visual é caracterizado pela simultaneidade, enquanto que o verbal é sucessivo. As imagens podem ocupar o espaço por meio de formas e cores ao mesmo tempo, enquanto que o texto se configura no tempo com sons articulados. A duração de uma imagem pode ser maior que a velocidade do texto em cena. O visual facilita a leitura, a indicação da enunciação pela imagem é imediata, por outro lado podem haver divergências na compreensão dos signos sonoros que são reconstituídos pelo apelo verbal.

Na prática teatral as imagens acontecem ao mesmo tempo, enquanto que o texto é dito frase por frase, sem o atropelamento de palavras. O sistema visual trabalha com o que é matéria, e o verbal com ondas sonoras. A duração de cada um acontece de acordo com o desejo do encenador, geralmente, o texto passa pelo palco de forma mais rápida do que a imagem. $A$ presença de intermediários é variante, o ator fala, mas também pode ser ouvido por uma gravação, a cenografia é montada por cenotécnicos, que podem surgir em cena se for necessário. A compreensão do todo dependerá do referencial, linguístico e imagético do espectador. A escolha pela imagem pode indicar a dificuldade de verbalizar o signo visual, assim como a escolha pelo textual pode acontecer pelo impedimento de concretização do enunciado. 
Não é possível definir o que vem primeiro, o verbo ou a imagem, isso depende do referencial. Espetáculos podem evidenciar características textuais ou imagéticas, de acordo com a proposta escolhida. Porém, o que cabe neste estudo é perceber que a visualidade é intrínseca ao fazer teatral.

Ao falar sobre o objeto teatral, Anne Ubersfeld (2013) afirma que o espaço teatral é composto por elementos concretos, cuja relevância é variável, e que esses elementos são os atores e seus corpos, o cenário e os acessórios. Sobre esses elementos concretos, o figurino assume papel de fundamental importância para o desenvolvimento da cena. A partir do seu caráter visual, o figurino auxilia a construção da personagem pelo ator, assim como a leitura do espetáculo pelo espectador.

\section{Traje de cena}

A roupa é uma convenção social. Todos os seres humanos cobrem o corpo por algum motivo, cobrir a nudez, embelezar-se são alguns exemplos. O teatro, enquanto expressão artística da sociedade, veste os seus personagens de acordo com a encenação, e essas vestes se denominam figurinos teatrais. O figurino tem a função de auxiliar a metamorfose do ator para cada personagem que ele vai interpretar. Com a vestimenta conta-se uma história.

O figurino teatral deve ser considerado como elemento integrante da ação cênica, sua potência significativa possui o mesmo valor que os outros elementos que compõem o espetáculo. O figurino é visual, e a sua finalidade é contribuir para a representação e construção da personagem. Por isso, pode-se afirmar que o figurino teatral é um conjunto de códigos. Esses códigos expressam características relativas à personagem e ao texto, como personalidade, preferências, contexto histórico e social. O figurino, na maioria das vezes, é utilizado a serviço de uma narrativa, seja ela tradicional ou pós moderna.

A definição de figurino teatral atravessa questões relativas a roupa, a indumentária e a moda. Convencionalmente, compreende-se roupa por aquilo que se veste, que cobre o corpo. A roupa esquenta o corpo do frio, também protege contra o calor excessivo. A moda é o sistema que dita as tendências da vestimenta na sociedade. O termo indumentária pode se referir a trajes de 
épocas e finalidades específicas, por exemplo a indumentária do renascimento, como também a indumentária do padre, do juiz, etc.

Figurino teatral também pode ser definido como traje de cena. Para Fausto Viana (2014), o traje de cena é a indumentária das artes cênicas, incluindo o teatro, a dança, circo, a performance, shows, entre outras ações espetaculares que exijam a construção de uma cena. Na performance, a pele pode ser abordada como traje cênico. A roupa, quando utilizada em uma cena, é considerada figurino, seja uma roupa do cotidiano ou uma indumentária.

Existem outras definições apresentadas por Viana (2014), como a de Barbara e Cletus Anderson, que afirmam que tudo o que o ator veste em cena deve ser considerado figurino, seja de tecido ou de qualquer outro material, das roupas íntimas até o lenço de bolso. Para Roubine (1998) o figurino compõe um conjunto de cores e formas que modificam o espaço cênico. Viana (2014) também apresenta a visão de Ariane Mnouchkine, para ela o figurino é "parte do interno" processo de criação da personagem pelo ator.

Com isso, é possível dizer que o figurino teatral é composto por todo material que veste o ator, o dançarino e o performer para cena, com a função de auxiliar a construção da personagem. O figurino através das cores, formas e materiais utilizados, é capaz de indicar características da personagem e do texto por meio de variações no espaço.

\footnotetext{
Um figurino pode indicar, de maneira geral: localização espacial ou geográfica; clima, época do ano; idade da personagem; sexo; ocupação, posição social e atividade; a hora do dia e a ocasião; período histórico em que a personagem vive; fatores psicológicos (VIANA, 2014, p.28).
}

Ao observar o material, o corte e as cores utilizadas na confecção de figurino, é possível definir características específicas de cada personagem. É comum criar a partir de estereótipos já difundidos, por exemplo, no ocidente as cores mais escuras indicam personagens soturnas, sóbrias, até mesmo elegantes, as cores mais claras se aproximam da ingenuidade e da pureza, e assim por diante. Cada cor possui um significado, e isso é pensado na hora de criar um figurino. Da mesma forma, algumas modelagens ficaram marcadas no imaginário social. As golas pontudas das pessoas cheias de personalidade, os babados arredondados das moças de família, ou por exemplo as malhas de vinil da mulher sexy e das sociedades futuristas. O tipo de material utilizado para 
confeccionar os figurinos vai complementar os signos presentes nos trajes cênicos. Tudo tem um sentido, e precisa estar de acordo com a encenação.

Não se deve excluir, ou diminuir a capacidade criativa do figurino. É possível fugir dos estereótipos e inovar com ideias e modos de fazer diferenciados. O cuidado está em tornar harmônico todos os elementos cênicos, se essa for a proposta estética do espetáculo (o que seria o contrário se a proposta fosse a desarmonia).

Outra influência exercida sobre o figurino vem da cultura local onde o espetáculo está sendo produzido (VIANA 2014), e também do contexto onde a trama se passa. O lugar onde o figurino é produzido pode ser percebido pelas características visuais e culturais presentes no traje cênico. É quase impossível separar a produção artística da localidade onde esta se insere, pois até mesmo os materiais para produção são adquiridos neste lugar, a não ser que tudo seja importado. O lugar da história também influencia, pois algumas características do povo e de seu vestuário serão demonstradas através do figurino, sejam reais ou fictícias.

O figurinista é o responsável pela elaboração do figurino, do croqui à roupa. Ele é o responsável por estudar as referências e apresentar ideias para o figurino, bem como as soluções para troca de roupa. A escolha da modelagem, o corte e a confecção, tudo fica a cargo deste profissional, que também deve cuidar dos tingimentos, bordados e deixar claro como efetuar a manutenção do figurino.

O melhor procedimento do figurinista é acompanhar o processo do início ao fim, desde os ensaios até as apresentações. Porém, não é isso que acontece na maioria das vezes, o figurinista geralmente é solicitado às vésperas da estreia o que dificulta a execução do trabalho em pouco tempo, e também atrapalha o processo do ator, que precisa estar familiarizado com o figurino na hora de entrar em cena. Para isso, é preciso conscientizar desde os alunos de cursos de teatro a grupos profissionais, que o figurino é parte integrante do trabalho do ator, e deve fazer parte do processo de montagem do espetáculo.

O figurino deve ser usado em favor da encenação, como elemento que integra o fazer artístico e cênico. Por isso, é significativo partilhar as experiências criativas com os profissionais envolvidos no trabalho de encenação, como o cenógrafo, o maquiador, o iluminador, e principalmente com os atores. A criação de figurinos perde sua força quando está excluída do 
processo de montagem do espetáculo. Sem falar que, quando um elemento cênico se destaca mais do que outro, a atenção do espectador pode ser desviada do foco central da cena.

Para exercer um bom trabalho o figurinista deve estar atento a algumas questões para a criação de figurinos, sendo elas: a opção estética da direção; o orçamento previsto; indicações do texto/roteiro e das falas das personagens; e as informações sobre luz e cenografia (VIANA, 2014). Essas questões influenciam a criação de figurinos. O contato primordial com o diretor e com o grupo é de fundamental importância para compreender o enredo e as opções estéticas e dramatúrgicas. O figurinista deve estar apto a apresentar croquis de figurinos de acordo com as referências do espetáculo. Na maioria das vezes, o texto dá indicações de cores de roupa, tipos de corte e até descrições detalhadas sobre o traje, isso deve ser levado em consideração a critério do encenador.

A iluminação e a cenografia devem compor um conjunto visual com o figurino, e por isso o diálogo com os responsáveis por essas áreas é essencial. A luz influencia nas cores dos tecidos dos figurinos, assim como o cenário e o figurino devem estar em harmonia para não chamar mais atenção do que é devido. Porém, é o orçamento disponível para confecção que vai indicar o tipo de material utilizado, se é possível usar o melhor tecido ou se terá que reinventar a partir de um material mais barato.

\section{Considerações finais}

O figurino teatral é componente integrante no fazer teatral. Além de contribuir para a construção da visualidade do espetáculo, o figurino pode indicar características das personagens representadas, facilitando o entendimento por parte do espectador.

A partir do que foi apresentado aqui, verifica-se que o figurino teatral está alcançando novos patamares, e o progresso nos estudos sobre esse tema, tem fortalecido o seu papel enquanto significante cênico. O fator primordial da visualidade cênica deixa de ser apenas a cenografia, e passa a ser o conjunto de diversos aspectos, entre eles o figurino.

Ao assumir a função de significante cênico, o figurino ultrapassa as barreiras na mera representação literal, ele alcança o nível do sensível e carrega todo o contexto envolvido, real ou abstrato. Enquanto o figurino era responsável apenas por vestir o ator, o processo criativo era 
menor e mais rápido, as vezes nem existia. Por outro lado, ao assumir novas funções, surgem novos modos de criar. A cada necessidade surgirá uma nova possibilidade. Com o avanço tecnológico, já é possível criar figurinos virtuais que interagem com o real, imaginem o que estar por vir no futuro. Evoé.

\section{REFERÊNCIAS}

PAVIS, Patrice. Dicionário de teatro. São Paulo: Perspectiva, 1999.

ROUBINE, Jean-Jacques. A linguagem da encenação teatral. 2. ed. Rio de Janeiro: Jorge Zahar, 1998.

SANTAELLA, Lucia; NOTH, Winfried. Imagem: Cognição, semiótica, mídia. São Paulo: Iluminuras, 2009.

UBERSFELD, Anne. Para ler o teatro. São Paulo: Perspectiva, 2013.

VIANA, Fausto; BASSI, Carolina (orgs.). Traje de cena, traje de folguedo. São Paulo: Estação das Letras e Cores Editora, 2014.

Artigo submetido em 29/12/2018, e aceito em 30/12/2018. 